\title{
Analysis on the Development Strategy of Xi'an Land Port Logistics Based on the Fourth Party Logistics
}

\author{
Weixia Yang \\ School of business \\ Xian International University \\ Xi'an, China \\ wxyang741117@163.com
}

\section{Keywords: Fourth-party Logistics, Xi'an Land Port Logistics, Supply Chain}

\begin{abstract}
Under the strategy of "One Belt and One Road" and western development, Xi'an's geographical advantages and basic functional advantages as well as its dominance in the nation's "Belt and Road" strategy have brought a great The advantages and opportunities to Xi'an land port logistics. However, the multimodal transport network of Xi'an land port logistics is imperfect; the design of logistics passage and circulation mode of cargo is lack. The use of advanced logistics technology of fourth-party logistics may achieve an effective reduction of the cost of logistics supply chain and obtain benefits. In this paper, on the basis of analyze the logistics development of Xi'an land port and the characteristics of the fourth party logistics, the author sets up the combination of the land port logistics and the fourth party logistics better. Finally, based on the fourth party logistics, the author put forward a series of development strategy of Xi'an land port logistics.
\end{abstract}

\section{Introduction}

The vigorous development of the third-party logistics has received widespread attention, but it still has some shortcomings in practice, and more and more can not meet the needs of customers, so the concept of fourth-party logistics has produced. With the development of the modern economy, the integration of resources around the world has further enlarged the scale of China's foreign trade and it expedited the exchange of information, technology, capital and logistics, all of which set higher requirements for the development of port logistics in our country. As a provider of supply chain solutions, the fourth party logistics plays an important role in the information exchange, logistics operation, resource integration and strategy formulation of the port. How to make full use of the fourth party logistics to improve the logistics capacity of the port, to play its role in modern economic and trade, for the development of modern port logistics is of great significance.

\section{Overview of related concepts}

\section{The definition of the fourth-party logistics}

The fourth party logistics is a business model that based on the third party logistics will provide customers with supply chain solutions by integrating capabilities and technology. In addition, it not only design a reasonable supply chain solutions to meet customer needs, but also conduct consultations and cooperation with third-party logistics companies, software suppliers, information technology providers, and government departments to maintain the stable operation of the supply chain development of customers. The main core task of the fourth party logistics is to further integrate the resources in a wider scope, which provides a solution for the bottleneck facing the logistics industry.

The fourth-party logistics not only control the management of logistics services, but also integration the entire logistics process through e-commerce. Therefore, high efficiency, low cost and human service mode are the key to the success of the fourth party logistics. The fourth-party logistics 
provide customers with functional integration services and expand business autonomy based on balance the ability of the third party logistics, technology and smooth management of trade.

\section{The characteristics of the fourth party logistics}

\section{Supply chain reengineering}

In the process of supply chain management in the logistics operation process, the third party logistics lack the integration of its system resources, there is a clear intermittent and local defects in supply chain. Through the reengineering of the supply chain, the fourth party logistics can make supply chain management comprehensive, comprehensive and system optimization.

4PL integrates customer and vendor information and technology systems through a multi-purpose, multi-process supply chain reengineering. 4PL vendors have enhanced their traditional management, and it has its own strengths in translating functions and processing operations across of supply chains.

The functions of node business of supply chain change

Enhance and refine the functionality of each supply chain node business by using new supply chain management technologies. Fourth-party logistics using advanced technology and organizational capacity management, and careful strategic thinking, integrate and improve the activities and processes of supply chain , and format the best solution.

Standardization and intensification

By promoting standardization process of the logistics industry, fourth-party logistics will not only promote the uniform standardization of logistics quality and technology, but also improve the standardization process of logistics management procedures and practices.Fourth-party logistics integration the ability of third-party logistics companies, management consultants and IT companies and integrate some of the relevant logistics resources, for which a set of supply chain logistics solutions effectively meet the diverse needs and complexity requirements.

\section{The development status quo and characteristics of the of Xi'an land port logistics}

\section{The introduction of $\mathrm{Xi}$ 'an land port}

$\mathrm{Xi}$ 'an land port is the economy pilot zones and the core functional areas ofmodern service industry built by the shaanxi provincial government in order to adjust industrial structure and transformate the evelopment mode of economic. and to build inland development and opening-up heights of the open and, is the shaanxi. It is important gripper, of a new starting point of the silk road economic belt , an important platform connecting the strategy of "one belt,one road", and a new engine of development and open of the inland areas.

$\mathrm{Xi}$ 'an land port is located in the northeast of the city of xi 'an , its planned control area is 120 square kilometers, and its planned construction area is 89.89 square kilometers. In accordance with the development path of the "Hong Kong - area - city", the development goal of building modern producer services new city and the silk road economic belt's largest international transshipment hub port and trade logistics base, the shaanxi provincial government form the basic pattern opening up relying on the three core platform of "xi 'an comprehensive free trade zone, xi 'an railway container terminal, xi 'an highway port. It will provides a solid guarantee for the "modern interconnectivity" through the iron transport system, the transportation corridor with the domestic and international port, and modern electronic information network.

Since its establishment, the state attaches great importance to the development of xi 'an international port area, and awarded 9 national brand of "national modern service industry innovation base", "national cross-border trade e-commerce pilot core service", "national advertising industrial park", "national e-commerce demonstration base" and other. For three consecutive years, it won the "China logistics demonstration garden", "shaanxi economy's most influential regional" and other honorary title, and its influence and radiation to foreign is prospective. 


\section{The status quo of logistics development in $\mathrm{Xi}$ 'an land port}

\section{The construction of Infrastructure equipment}

\section{(1)Transport hub}

First of all, Xi'an International Port District relies on its unique geographical advantages is an important hub connecting Central Asia and it locates a leading position in the development of contemporary logistics. Secondly, Xi'an International Port District is closely linked to national highway network, that is very helpful to economic development of Xi'an.

Its some infrastructure is maturing. There are built 15 roads and six roads under construction. The construction of large-scale freight vehicles dedicated channel make it more convenient circulation and distribution, and the construction of a new building make it in the transport process without disturbing the development. At the same time it began to implement environmental planning, improve environmental quality and expand the green area around the city and the park.

\section{(2) Urban supporting facilities}

There are the following points in the urban supporting aspect: Firstly, The national logistics collection and distribution system has also been formed, which takes Xi'an as the center and connects with the provincial logistics and transportation system. Secondly, The development mode of logistics industry is in line with the main industry in Xi'an And mutual promotion is gradually established and perfect, which is made up of modernized logistics system of information and application of means of production and living material. Finally, in recent years, Xi'an logistics enterprises continue to grow and develop, and related professional knowledge and skills are gradually becoming specialized and advanced.

The construction of information platform

In the development of thought and key work of multi-modal transportation, the entire process design is in accordance with the principle of "optimizing the process, building both transport and construction", it is around the advantages of Xi'an land port, and take inland collection, road transport, rail transport, Train-air-truck Transportation, big data as a pivotal node. We should enhance the traffic circulation system of the node of Xi'an land port from the aspects of informationization, infrastructure, transport organization and transportation in order to meet the needs of a variety of efficiency requirements under the mode of intermodal transport of each intermodal route. We also should The use of Internet of Things and other modern information technology means to speed up the information inside and outside the port of Xi'an interoperability information and build multimodal transport integrated information service system to achieve the development of Xi'an Information Port Authority.

\section{Operation status quo of logistics}

Xi'an International Port Area is a key area in the development of modern logistics for bonded logistics, container logistics, inter-city logistics and logistics supply chain management.

\section{Bonded logistics}

Relying on the unique advantages of Xi'an Integrated Bonded Zone, Xi'an International Port Area carry out special supervision and management of welded pipe in tax, foreign exchange and customs clearance policies, carry out bonded warehousing and carry out international logistics, import and export trade of various value-added services of logistics information; and explore various innovative business development .It is essential for a large-scale commodity trading center.

Container logistics

Xi'an Railway Container Terminal Center relies on the core of multimodal transport system, such as the combination of maritime transport and railway transport, road and rail transport, air transport and rail transport, forming a container logistics integration such as warehousing, storage, distribution, sorting, packaging and distribution , transportation, inspection, maintenance and other services. 
Logistics supply chain management

When the logistics enterprises implement supply chain management, it may through some value-added services, related information systems provide customers with more comprehensive and efficient service. Xi'an International Port Area introduce logistics enterprises to integrated services and related value-added e-commerce transactions; encourage local enterprises to purchase, sale and other related outsourcing services, building international procurement, international distribution and worldwide distribution management center.

\section{The role of the fourth party logistics in the development of Xi'an land port logistics}

\section{Conducive the land port logistics to supply chain management}

Based on the third-party logistics, the fourth-party logistics put to use advanced information technology and supply advanced experience of chain management to provide an integrated consulting services for logistics company, so as to allows the supply chain logistics nodes enterprises interact and cooperate. In addition, the fourth party logistics not only integrates multiple logistics service providers such as transportation, storage, handling, agency, packaging and processing, distribution and information processing, but also integrates the resources between various enterprises to provide customers convenient and efficient "one-stop" logistics services. So that it can optimize and integrate the supply chain management of inland ports so as to reduce costs and improve the efficiency of logistics operations and encourage more logistics to devote more time and energy to their core businesses to speed up the development of the logistics of inland ports.

\section{Land-port logistics and enterprises and customers timely carry out information transmission and sharing}

The transfer and sharing of information plays a crucial role in the development of land port logistics. The necessary prerequisite for the development of business cooperation between the two enterprises is the transmission and sharing of information. The exchange of information promotes the supply and demand of products and the logistics to be carried forward and the development of the whole supply chain can also be promoted. For all enterprises, demand forecasting, inventory status, production planning and sales plans are important are data of supply chain. With improving e-commerce platform and integrating modern information technology resources, the fourth-party logistics can keep track of supply and demand information of enterprise supply chain and integrate transport logistics, storage status with enterprise planning and business, which ensure that enterprises can timely supply of raw materials, as well as the contract The finished product transportation and other business required for the smooth progress.

\section{Help to determine the role of land port in the supply chain}

The fourth-party logistics integrates land port logistics into the supply chain, and provide supply chain solutions to enterprise, it play a crucial part in the deployment of each supply chain logistics The cooperation and development between the land ports and various transport routes are all aimed at enhancing each and every one of its roles in the supply chain node. By integrating resources and information, the fourth party logistics integrates social resources and industry innovation so that the land port industry can rapidly develop in the supply chain system and strengthen its role and position in the supply chain.

\section{Create economic development direction for land port}

Both the land ports and the development of regional economic are mutual promotion and mutual development. For example, when Xi'an builds the land port, it proposes important strategic plan of "constructing the inland port firstly, then building the development zone and finally building the western new town". Nowadays, our country is a logistics development based on modern service industry and productive service industry. It has formed a certain scale in informationization, 
international trade and domestic trade, and has a powerful driving role in the development of regional economy. As the first comprehensive bonded zone in Northwest China, Xi'an International Port Zone promotes the development of international trade in the entire region.

Strong economic development capability and well-developed industrial integration are strong support points for the rapid development of the land ports. Moreover, the land ports need to improve some of their own infrastructure, equipment and operation capabilities, and are also closely following the trend of economic development in order to speed up economic development as soon as possible. The fourth party logistics must keep up with developments in economy at any time and make the land port provide the frontier and trend of the latest economic development for the economic hinterland and promote the development of the logistics in the port and port and provide impetus and direction for its development.

\section{Development strategy of Xi'an land port logistics based on the fourth party logistics}

The fourth party logistics is relied on the development of land port, its advantages is that based on the supply chain management advantages of the formation and optimization the supply chain, Plan for the development of land port logistics and implement supply chain logistics business docking information from a holistic perspective. So as to it can form stable logistics alliance, and ensure the smooth implementation of the logistics business, and strive to improve the quality of land port management and service. Therefore, the development mode of the fourth party logistics Introduction of post-modern land port logistics is as follows:

\section{Strengthen the construction of supply chain information platform}

Xi'an land port logistics should strengthen the construction of supply chain information platform. The improvement of land port information platform capabilities plays an important role in the development of land port logistics. The core of the construction of land port information platform is establishment of its information to improve the search and processing of logistics service capabilities. The construction of integrated information platform will take land port, customs, commodity inspection, agents, shippers as an organic whole. By developing supply chain information platform, land port enable logistics companies to meet the needs of the logistics information needs, and apply these information together to the supply chain management. The fourth-party logistics plays an important role in supply chain management. Supply chain information has a strong integration effect. Through the construction of the fourth-party logistics information platform for the construction of the land port supply chain, the integration of land port logistics, highway logistics, railway logistics, pipeline logistics and aviation logistics will be further coordinated with the branch logistics enterprises in the supply chain , and improve the smoothness of logistics transport in land port.

\section{Import land ports into the supply chain}

Importing land ports into the supply chain is important to land port logistics, because it enables land ports integrated into the supply chain, and it can improve and strengthen the role of land port in the supply chain in the following ways: Firstly, It is imperative to integrate the development of industrial clusters in the economic hinterland, the latest developments in the modern market and the development trend to ensure that the supply chain enters a stable state of development. Secondly, the cooperation customers in the supply chain can make the choice based on the application of the fourth-party logistics and the credit, operation and development capabilities, institutional arrangements and information technology among the cooperative enterprises in the supply chain, it play a significant role in the land port logistics, so it can effectively carry out planning and coordination of land port. Finally, the introduction of the fourth-party logistics can make the performance of land ports and business operations closely related. The reasonable and equitable distribution of benefits to both ports and enterprises can bring a solid guarantee to cooperation. 


\section{Forming a dynamic alliance between the fourth party logistics and land port logistics}

In fact, forming a dynamic alliance between the fourth party logistics and land port logistics can make land port logistics improve its development when it use the fourth party logistics. Actually, the use of the fourth party logistics is to integrate the enterprises in the supply chain, integrate the land port, logistics, information and technology to service providers and customers, so that under the influence of the market mechanism, they will format a long-term and stable dynamic alliance based on mutual benefits and the. For this reason, it needs that the land port should strengthen exchanges and cooperation with other interest groups in the community. The following two points are taken. Firstly, based on the application of the fourth party logistics, the related logistics activities are strengthened and the logistics function of the land port is enlarged. The supply chain network is used to extend the port transportation function, trade function and bonded service inland. At the same time, the expansion of logistics functions has also expanded the space for inland manufacturing, logistics and land port cooperation. For example, it can create enormous attraction for logistics enterprises to enter the land ports, which enable the land ports and logistics enterprises to jointly establish a logistics base and cooperate with each other. It also has the role of strengthening the joint mechanism of the two sides and giving full play to its role.

\section{Summary}

To sum up, from the development status of Xi'an land port logistics and the characteristics of the fourth-party logistics this article analysis how to make full use of the fourth-party logistics in the development and application of logistics in Xi'an land port, and how to combinate them. How to make full use of the fourth party logistics to improve the logistics ability of the land port. in order to give full play to its role in the modern economy and trade, to make a scientific, rational and clear planning for its logistics development strategy of the land port logistics, the development of logistics in Xi'an land port has an important significance. Xi'an land port logistics develop faster and faster under driven by the fourth party logistics.

\section{References}

[1]Chuting Hu. Significance and Countermeasures of Developing Logistics Industry in Jilin Province

[J]. Chinese market, 2016 (02)

[2]Yangyang. International Dams Simulation Based on System Dynamics [J]. Journal of Wuhan University of Technology, 2014 (12)

[3]Zhoukun. Analysis of the Fourth Party Logistics in Hefei and Countermeasures [N]. Journal of Jiangxi University,2015, (04)

[4]Jiajun. Brief Analysis of Logistics Park Planning and Design [J]. Real Estate Guide,2015, (2)

[5]Wenchao Zhou. Research on the Development of the Fourth Party Logistics in China [J]. Land and Resources Research,2015

[6]Liu hao. Upgrade Xi'an Inland Port Function and Establish New Inland Transportation [J]. China Railway,2014;(4) 